\title{
ANALISA MANAGEMENT DAN CAREER OPORTUNITY UNTUK MENINGKATKAN KINERJA ORGANISASI
}

\author{
Indah Kusumawati \\ Dosen Fakultas Ekonomi dan Bisnis Program Studi Manajemen \\ Universitas Muhammadiyah Tangerang
}

\begin{abstract}
ABSTRAK
Penelitian ini bertujuan untuk menguji efek work-life balance dan subjective career success dalam pengaruh career management terhadap kepuasan kerja pada karyawan. Data dikumpulkan dengan teknik convinience sampling pada 91 karyawan di beberapa Bank di Jakarta. Pengujian menggunakan data yang telah teruji validitas dan realibiltas, dengan menggunakan software SPSS V.22 dan macros inderect Hayes 2013. Hasil uji membuktikan work-life balance dan subjective career success signifikan memediasi pengaruh career management terhadap jobsatisfaction. Sementara pengaruh langsung career management terhadap job satisfaction tidak signifikan, sehingga mediasi menjadi mediasi sempurna.
\end{abstract}

\section{Kata Kunci : Career Management, Work-Life Balance, Subjective Career Success, Job Satisfaction}

\section{PENDAHULUAN}

Karir telah didefinisikan sebagai proses seumur hidup yang tercipta dari serangkaian aktivitas dan sikap atau kebiasaan yang berhubungan yang terjadi dalam kehidupan pekerjaan seseorang (Hall dan Associates 1996). Karir juga ditampilkan sebagai pola dari pengalaman yang berhubungan dengan pekerjaan, seperti posisi, tugas ataupun aktivitas pekerjaan, pengambilan keputusan, dan interpretasi yang subjektif dari kejadian yang berhubungan dengan pekerjaan seperti aspirasi, pengharapan, nilai-nilai, kebutuhan dan perasaan mengenai pengalaman pekerjaan tertentu, yang membentang di sepanjang perjalanan pelajaran hidup seseorang (Greenhaus et al., 2000). Dalam kehidupan moderen, karir yang sukses menjadi dambaan baik bagi tiap orang. Kesuksesan karir banyak dipandang sebagai suatu pencapaian dalam hidup yang tidak terlepas dari kesuksesan hidup secara menyeluruh. Kesuksesan karir bagi tiap orang menjadi tujuan yang sering dikaitkan dengan kesempatan memperoleh promosi, duduk dalam hirarki, rank dan retensi (Hall dan Chandler, 2005; Judge et al.,1995).

Kesuksesan karir yang berdampak pada meningkatnya jabatan, kompensasi yang terukur disebut kesuksesan objektif sedangkan bagaimana hasil tersebut berdasarkan persepsi dengan pengalaman masing-masing individu yang menjalaninya disebut kesuksesan subjektif. Perkembangan riset menunjukkan kesuksesan yang diperoleh dari sisi objektif maupun subjektif tetap 
harus memiliki arti yang mendalam secara psikologis (Heslin 2005; Seibert dan Kraimer 2001; Johnson dan Stokes 2002; Arthur et al., 2005; Orpen 1998). Kesuksesan karir juga berhubungan dengan berbagai faktor yang dihubungkan dengan social cognitive career theory (Rasdi, et al., 2009) yaitu karakteristik inidividu, faktor organisasi, pembelajaran dan pengalaman, serta interaksi timbal balik individu dan lingkungan.

Dewasa ini, fenomena kesuksesan karir bagi seseorang menjadi gambaran masyarakat moderen. Kesuksesan karir tidak lagi hanya didominasi kaum pria tetapi juga kaum wanita. Fakta menunjukkan bahwa wanita sudah sejak lama mampu memberi kontribusi terhadap kesejahteraan keluarga bahkan perekonomian suatu negara dengan kinerjanya yang tinggi. Hasil riset menunjukkan pekerja wanita yang mencakup seperempat dari angkatan kerja pada tahun 1940 naik menjadi setengah pada tahun 80an dan diperkirakan menjadi 2/3 dari jumlah angkatan kerja pada tahun 1995 (Bowen dan Hisrich 1986). Fakta riset tersebut hingga kini terus meningkat. Rumah tangga dengan ayah bekerja dan ibu di rumah dewasa ini semakin menurun. Wanita bekerja pada dasarnya meningkat dari waktu ke waktu. Hal ini selain karena keinginan untuk meningkatkan pendapatan tetapi juga karena kepuasan yang ditimbulkan oleh karir menjadi sama baik bagi pria maupun wanita (Farmer 1985; Schneer dan Reitman 1993).

Kesuksesan karir bila dibahas dari klasifikasi wanita dan pria dari studistudi terdahulu tampak signifikan berbeda. Wanita biasanya mengalami diskriminasi dalam promosi dikarenakan peran ganda yang dilekatkan pada kaum wanita untuk mengurus rumah tangga dianggap berdampak pada kecendenrungan untuk lebih sering bolos dan lamban dalam penyelesaian tugas-tugas. Timbulnya work family conflict pada wanita karir yang memiliki peran ganda dapat menurunkan kepuasan karir dan kemajuan karir (Stroh et al., 1996) pemenuhan karir (Trenbunsel et al., 1995) dan berbagai kepuasan lain seperti kepuasan kerja dan hidup (Kossek dan Ozeki 1998).

Dalam riset Nikandrou et al., (2008) ditemukan bahwa wanita lebih semangat berkarir bila mendapat dorongan keluarga. Wanita juga akan mengalami kendala karir bila workfamily conflict tidak dapat dihindari (Vianen et al., 2002). Oleh karena itu kriteria sukses karir yang dikemukakan Finegold dan Mohrman (2001) dimana hasil riset mereka terhadap 4500 pekerja berpendidikan dan manager-manager dari 8 negara menemukan WLB menjadi faktor penting dalam setiap fase karir. Temuan tersebut merupakan dukungan terhadap pendapat bahwa kesuksesan karir tidak akan bisa terlepas dari kriteria kehidupan di luar kerja. Oleh karena itu, dukungan organisasi terhadap work-life balance bagi wanita karir turut menentukan sukses karir subjektif.

Greenhaus et al., (2000) menyatakan bahwa manajemen karir juga berhubungan dengan pilihan individu untuk berinisiatif atau mengintervensi arah karir yang diinginkan. Semua kemungkinan dalam memajukan karir seperti peningkatan kompetensi maupun jalur yang ditempuh untuk promosi dapat dilakukan secara proaktif. Manajemen karir yang 
ditujukan untuk meningkatkan kesuksesan karir tidak selalu berdampak pada kepuasan karir yang dirasakan. Bagaimana wanita merasakan sukses dalam bekerja namun kehilangan waktu dalam keluarga. Pekerjaan yang sukses dapat membawa kegagalan psikologis. Contoh, sukses dalam tugas namun kehilangan waktu bersama keluarga (Bartolome dan Evans 1981). Bagaimana wanita berpartisipasi dalam manajemen karir untuk kesuksesan karirnya yang sekaligus meningkatkan work-life balance yang dirasakan dan dapat meningkatkan kepuasan kerja, menjadi topik menarik untuk diteliti. Kesuksesan karir subjektif tidak dapat diabaikan sebagai bagian dari hadirnya kepuasan kerja. Kesuksesan karir subjektif bagi wanita karir menjadi penting dalam manajemen karir.

\section{KAJIAN TEORITIS DAN HIPOTESIS PENELITIAN \\ Career Success}

Teori-teori kesuksesan karir telah berkembang dari waktu ke waktu. Hughes menyatakan objective career success merupakan kesuksesan yang dapat diamati langsung, dapat diukur dan diverifikasi, misalnya besaran gaji, promosi, Hughes (1937; 1958) dalam Heslin (2005). Riset-riset terkait kesuksesan karir sepanjang 1980-1994 lebih banyak (75\%) menggunakan kriteria objective success (Arthur dan Rousseau 1996) namun, setelah itu riset karir mulai menggunakan kriteria subjective career success (Hall et al., 2002).

\section{Subjective Career Success (SCS)}

Suatu konstruk karir sukses subjektif selalu konsisten dengan sukses psikologi dan nyatanya mendahului hasil objektif. Pandangan subjektif adalah sukses psikologi, makna dari sukses psikologis akan tercapai bila seseorang secara luas menggunakan usaha terhadap tantangan tujuan yang personal yang berarti, dan terus dapat mencapai tujuan ( Locke 1990a). Sukses juga akan mengarahkan pada suatu peningkatan level personal dan self esteem, identitas yang lebih kompeten, peningkatan keterlibatan pada area karir pekerjaan (Hall dan Chandler 2005). Hall juga menambahkan bahwa tidak selalu objektif sukses menghasilkan subjektif sukses.

Karir sukses subjektif meliputi reaksi nyata dan antisipasi yang berhubungan dengan perolehan antar luasnya waktu daripada suatu kepuasan sesaat (Greenhaus et al., 2000), luasnya outcome seperti identitas (Law et al., 2002) atau tujuan (Cochran 1990) dan juga direfleksikan standar personal yang tergantung pada tujuan (Gattiker dan Larwood 1988). Kriteria sukses dihubungkan pula dengan hasil-hasil karir seperti work-life balance (Heslin, 2005; Finegold dan Mohrman 2001), tujuan (Cochran 1990), keberartian (Wrzesniewski 2002), transcendence (Dobrow 2004), kontribusi dari pekerjaan (Hall dan Chandler 2005). Kesuksesan karir pada wanita diasumsikan lebih banyak dipandang dari kesuksesan karir subjektif dan relevan dengan konflik peran ganda yang dirasakan.

A self referent criteria menyatakan other criteria dimana individu cenderung membandingkan sukses atas karirnya dengan pihak la in seperti rekan sealumni, masyarakat sosial disekitarnya (Heslin, 2005). 
Asumsi-asumsi ini membawa pemahaman akan karir sukses tidak selalu sama bagi tiap orang, dimana uang dan promosi tidak selalu membuat orang merasa sukses (Hall et al., 2002; Korman et al., 1981; Schein 1978). Dengan demikian kepuasan kerja yang tinggi tidak selalu sepenting menjalani karir sukses subjektif bila akhirnya semua itu diarahkan pada kesehatan, relasi keluarga atau personal value lainnya.

\section{Career Management}

Untuk mencapai kesuksesan karir organisasi sebagai pihak yang dapat mengintervensi karir menjadi penting dalam mengakomodasi motivasi karir individu. Baruch (2004) menyatakan bahwa karir adalah properti individual, namun pada kenyataannya organisasilah yang akan merencanakan dan mengatur karir dari para karyawannya. Bagaimanapun juga, selama beberapa dekade terakhir, telah banyak ditemui pemikiran bahwa tiap individu juga bertanggungjawab untuk memenuhi dan membangun karir mereka sendiri dari pada menyerahkan sepenuhnya pada pihak organisasi. Organizational career management (OCM) berhubungan dengan program pengembangan karir yang diberikan organisasi sebagai proses dukungan da lam pencapaian sukses karir anggotanya (Ng et al., 2005; Chen et al., 2004; Orpen 1994). Dengan OCM diharapkan organisasi dapat merencanakan dengan baik dukungan bagi tiap individu untuk kesuksesan karir, yang meliputi career appraisal, career development and career training. Career appraisal adalah indikator CM dengan item-item yaitu career advice, appraisal, career discussion, clear feedback, organizational support sedangkan career development terdiri dari item dual ladders, financial support, job rotation, job posting, dan succession planning. Indikator career training terdiri dari item in house training, career workshop, dan external visit (Kong, et al.,2014) yang mana career management diketahui dapat meningkatkan karir kompetensi (Kong et al., 2012), job satisfaction (Kong et al., 2014).

\section{Work-life Balance}

Work-life balance secara luas
didefinisikan sebagai tingkat keterlibatan yang memuaskan atau „,fit" antara berbagai macam peran dalam kehidupan pribadi seseorang. Meskipun definisi dan penjelasannya bermacammacam tetapi secara umum WLB diasosiasikan dengan keseimbangan atau perbaikan harmoni kehidupan yang dirasakan (Hudson, 2005). Work-life balance adalah suatu keadaan seimbang yang dirasakan dalam peran seseorang di pekerjaan, keluarga, komunitas maupun dalam waktu luang (Crooker, 2002) yang menjadi salah satu isue yang banyak diangkat dewasa ini. Keseimbangan work- life seperti yang telah dibahas dapat memberi dampak/output positif bagi individu dan organisasi (Hogarth et al., 2000). Beberapa penelitian menyatakan praktek dukungan terhadap keseimbangan kehidupan dan kerja atau Work-life Balance (WLB) dapat digunakan untuk mempertahankan karyawan yang berkualitas, meningkatkan moral karyawan, komitmen dan kepuasan kerja mengurangi masalah pekerjaan dan stres, meningkatkan kemampuan merekrut dan mempertahankan 
karyawan yang berbakat dan bernilai (Lewison 2006; Cappelli 2000).

\section{Job Satisfaction}

Beberapa riset mengaitkan kepuasan kerja sebagai hasil dari kondisi yang berhubungan dengan perbedaan persepsi, desakan motivasi, demografis dan psikologis, tindakan dan kondisi (Michalos 1985). Kepuasan kerja juga merupakan respon positif yang dinyatakan pada pekerjaan maupun lingkungannya. Banyak faktor yang dihubungkan dengan kepuasan kerja, seperti yang telah dinyatakan Hezberg dalam teori 2 faktor bahwa motivator faktor seperti prestasi, pekerjaan itu sendiri, kemajuan, promosi dan pengakuan menjadi pendorong kepuasan kerja (Quick dan Nelson, 2011). Kepuasan kerja dapat dipertimbangkan dalam 6 dimensi yaitu work-intrinsic, convenience, financial, relation with co worker, career opportunities dan resource adequacy (Kalleberg 1977).

\section{Hipotesis Penelitian}

Adapun hipotesis penelitian ini, sebagai berikut:

\section{Pengaruh Career Management, WLB dan SCS terhadap Job Satisfaction.}

Kepuasan karir merupakan indikator dari kesuksesan karir terutama yang berkaitan dengan kesuksesan karir yang subjektif. Manajemen karir yang tepat dan direncanakan dengan baik dapat meningkatkan kepuasan karir (Barnett dan Bradley, 2007). Career management dalam dimensi career advice, career training dan career development dapat meningkatkan peluang untuk memperoleh kemajuan karir sehingga harapan individu terhadap karir yang baik dan ideal dapat terwujud (Kong et al., 2014) di sisi lain dukungan organisasi, personaliti dan person job fit signifikan berpengaruh terhadap kesuksesan karir (Said et al., 2015)

Organisasi sebagai pihak pemberi kerja sudah semestinya memperhatikan karyawan dengan menyediakan fasilitas dan kebijakan agar karyawan dapat bekerja secara kondusif untuk menghasilkan kinerja yang baik (Zeytinoglu et al., 2007). Hal ini mendesak khususnya bagi karyawan wanita dengan peran gandanya. Di pihak la in politikus atau pemerintah dapat pula ikut ambil bagian dalam membuat undang-undang dan peraturan yang berpihak kepada kualitas hidup pekerja dalam memperoleh WLB seperti yang telah dilakukan di negara-negara maju (Waren et al., 2009).

Penanganan career management yang tepat dapat menyesuaikan rencana karir karyawan dengan kondisi keluarga sehingga dapat berjalan dengan kondusif (Sonnenfeld dan Kotter, 1982). Studi mengenai hubungan career management dengan WLB memang terbatas, salah satu studi yang relevan dilakukan Cohen et al.,(2007) menyatakan bahwa ada hubungan yang positif antara work family conflict dengan peningkatan promosi karir (Van Vianen dan Fischer 2002). Cohen et al., (2007) menyatakan beberapa hipotesis tentang kesuksesan karir yang 
berhubungan dengan karir wanita yang dibandingkan dengan pria pada para guru di Israel. Hasil penelitian mereka membuktikan bahwa sebagai mediating variabel work family conflict berpengaruh sangat signifikan positif dengan promosi sedangkan konflik karena keinginan dipromosi dan family work conflict berpengaruh signifikan negatif terhadap promosi. Riset juga membuktikan individu yang mengaitkan pilihan karir lebih kuat pada hirarki management akan merasakan kesuksesan karir objektif sedangkan yang menyesuaikan karir dengan kehidupan di luar kerja lebih merasakan kesuksesan karir subjektif, dengan kata lain kesuksesan dalam promosi cenderung berpengaruh dengan kesuksesan karir yang objektif (Tremblay et al., 2014).

\section{H1: Career management dapat meningkatkan subjective career success}

\section{H2: Career management dapat meningkatkan work-life balance}

Banyak riset telah menghubungkan work-life balance dengan meningkatnya kepuasan kerja (Machucha et al., 2015; Quensenberry dan Trauth 2007; Aryee et al., 2005; Perons 2003; Fonseca dan Verma 2001b; Saltzste in et al., 2001; Aryee et al., 2005; Anderson et al., 2010), kesuksesan karir (Nikandrou et al., 2008), komitmen organisasi (Bielby 1992) dan menurunnya turn over intention (Lazar et al., 2010). Penelitian Malik dan kawan-kawan di Pakistan terhadap 175 orang dokter pada beberapa rumah sakit yang berbeda juga menunjukkan WLB bepengaruh signifikan kuat terhadap kepuasan kerja (Malik et al., 2010). Flexitime sebagai kebijakan kapitaslisme moderen semestinya dapat membuat karyawan lebih produktif dan bahagia dimana WLB dengan program-program flexitime dikemukakan dapat meningkatkan kepuasan kerja (Scandura dan Lankau 2007; Fonseca dan Verma 2001b). Dukungan organisasi baik secara formal (family friendly policies) maupun informal (seperti dukungan rekan kerja atau supervisor) dapat menurunkan job stress (Thompson dan Prottas 2005). Hal ini menjadi issue penting yang sering diabaikan, khususnya di Indonesia.

\section{H3: Work-life balance berpengaruh terhadap kepuas an kerja}

Kesuksesan karir objektif hanya sementara, ketika sukses dalam satu fase maka akan menggerakkan seseorang untuk mempelajari karir baru berikutnya. Jadi secara psikologis kepuasan hanya pada level tertentu dan akan terus ingin diperbaharui. Lebih jauh lagi sejak abad 21 orang dapat mempersepsikan pengalaman kesuksesan karir dengan cara berbeda seperti, perpindahan pada sisi lain, pergeseran ke jalur berbeda, tentang organisasi maupun aspirasi yang disebut multidirectional. Konsep kesuksesan karir telah bergeser dari cara pandang tradisional (Sullivan 
1999). Model sistem karir yang baru membutuhkan perubahan kecocokan bagi organisasi dan lingkungannya. Sehingga sukses karir saat ini memiliki berbagai kriteri pilihan seperti kepuasan dari dalam, life balance, otonomi dan kebebasan, dan berbagai self perception lain.

Judge dan kawan-kawan mendasarkan riset mengenai kesuksesan karir dengan definisi bahwa kesuksesan karir adalah psikologis positif atau hasil kerja atau pencapaian-pencapaian yang berakumulasi dari hasil penga laman kerja (Judge et al., 1995). Dengan demikian kesuksesan karir tidak hanya dinilai oleh pihak lain yang mengukurnya dengan ukuran objektif tetapi juga dapat dinilai sendiri oleh individu yang menjalaninya sesuai dengan tujuan yang ingin dicapainya (Gattiker dan Larwood 1990). Kesuksesan subjektif juga diartikan sebagai penilaian individu dalam pencapaian karirnya (Stumpf, 2012; Seibert dan Kraimer, 2001), penilaian terhadap kemampuan diri (Chang et al., 2012) dan kepuasan yang dialami (Burke, 2001; Judge et al., 1995).

Para pakar teori dan praktisi sepertinya menerima asumsi yang menyatakan bahwa hampir setiap orang mencari kepuasan dalam pekerjaannya (Jepsen and Sheu 2003). Penelitian lain, Shujaat et al., (2013) meneliti dampak dari pengembangan karier terhadap kepuasan karyawan di Private Banking Sector Karachi, penelitian ini dilakukan terhadap 395 sampel dari karyawan Private Banking Sector. Penelitian membuktikan adanya hubungan positif antara pengembangan karier (career management) dengan kepuasan kerja karyawan dalam sektor perbankan. Riset lainnya dilakukan Anderson et al., (2010) juga membuktikan dukungan organisasi dalam bentuk informal yang diberikan supervisor dan coworker berpengaruh positif terhadap kepuasan kerja.

\section{H4 : SCS dapat meningkatkan Job Satisfaction \\ H5 : CM dapat meningkatkan Job Satisfaction}

Sebagaimana dinyatakan sebelumnya, banyak wanita karir yang berhenti bekerja setelah menikah dan mempunyai anak khususnya untuk profesi tertentu yang jam kerjanya sangat ketat (Herman 2006; Crompton dan Lyonette 2006; Schilling 2012). Relevan dengan hal tersebut, Santos (2015) menyatakan kesuksesan karir wanita lebih banyak mempertimbangkan work-life daripada ukuran objektif yang bersifat eksternal, hal ini juga didukung riset-riset yang membuktikan bahwa wanita karir lebih menganggap penting work-life balance, work stability, dan pemeliharaan kesehatan di tempat kerja maupun di luar tempat kerja (Dolan et al., 2011; Dyke Dan Murphy 2006 dalam Santos 2015).

Wanita karir dalam menjalankan karirnya biasanya merencanakan karir sukses dengan memasukkan peran sebagai orangtua sebagai pilihan bersamaan 


\begin{abstract}
dengan kemajuan karinya.
Pertimbangan dalam career management sebaiknya memasukkan situasi peran dalam keluarga sehingga rencana karir dapat mengakomodasi peran yang mendesak dalam keluarga yang bersifat sementara dan kemudian menyesuaikan rencana karir yang tepat (Ussher et al.,, 2015; Afiouni dan Karam, 2014). Dengan demikian wanita diperkirakan akan membuat pilihan yang sesuai antara keluarga dan karir. Riset yang relevan dilakukan Straub (2007) dimana WLB dibuktikan dapat dipengaruhi oleh kebijakan dan praktek dukungan pada beberapa perusahan yang ada di negaranegara Eropa. Riset ini menunjukkan perusahaanperusahaan tersebut mengimplementasikan sejumlah praktek dukungan. Ketika flexible work arrangement ditawarkan pengaruh keluarga terhadap kerja atau kerja terhadap keluarga signifikan terhadap Kepuasan Kerja (Pasewark dan Viator 2006)
\end{abstract}

\section{H6 : SCS dapat memediasi pengaruh CM terhadap Job Satisfaction \\ H7 : WLB dapat memediasi pengaruh $\mathrm{CM}$ terhadap Job Satisfaction}

\section{Model Penelitian}

Dari berbagai uraian dan hasil riset yang telah dibahas dalam mendukung hipotesis penelitian, maka diusulkan suatu model penelitian tentang kepuasan kerja wanita karir yang dapat dipengaruhi career management dan dimediasi work-life balance dan subjective career success seperti pada figur berikut.

$\mathrm{H}_{1}$ : Career management (CM) dapat meningkatkan subjective career success (SCS)

$\mathrm{H}_{2}$ : Career management dapat meningkatkan work-life balance (WLB)

$\mathrm{H}_{3}$ : WLB berpengaruh terhadap Job Satisfaction

$\mathrm{H}_{4}$ : SCS dapat meningkatkan Job Satisfaction

$\mathrm{H}_{5}$ : CM dapat meningkatkan Job Satisfaction

$\mathrm{H}_{6}$ : SCS dapat memediasi pengaruh CM terhadap Job Satisfaction

$\mathrm{H}_{7}$ : WLB dapat memediasi pengaruh CM terhadap Job Satisfaction

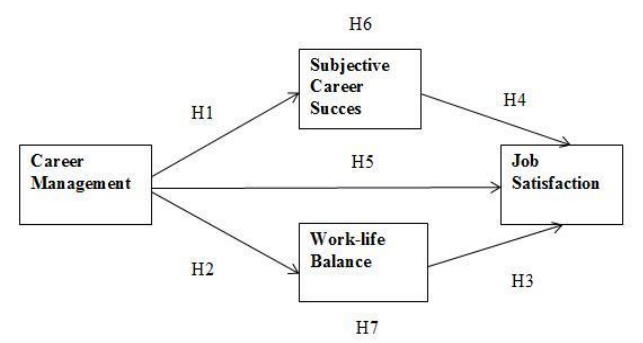

Gambar 1 Model Penelitian

\section{METODE PENELITAN}

Penelitian ini dilakukan terhadap responden wanita yang bekerja pada beberapa Bank di Jakarta pada pertengahan tahun 2016. Pemilihan responden wanita didasarkan pada pemikiran bahwa wanita biasanya lebih memilki kendala dalam berkarir mengingat perannya yang cukup besar untuk mengurus rumah tangga terutama di Indonesia yang masih memiliki pandangan tradisional mengenai gender (Hadiz dan Eddyono 2005). Namun, dewasa ini diketahui wanita menikah 
dengan peran ganda dapat sekaligus menjadi wanita karir yang sukses.

\section{Sampel}

Metode pengambilan sampel nonprobability, yaitu yang menyesuaikan diri dengan kriteriakriteria tertentu (Cooper dan Schindler 2000). Responden (sampel) penelitian ini adalah wanita bekerja dan telah berkeluarga, dimana wanita tersebut minimal telah bekerja selama 3 tahun. Kriteria 3 tahun dimaksudkan agar responden telah melewati masa orientasi dan lebih dapat memberikan jawaban yang representatif karena telah dimungkinkan untuk mengikuti program pengembangan karir. Populasi dari penelitian ini adalah wanita karir yang bekerja pada bank-bank di Jakarta yang jumlahnya relatif sulit untuk diketahui karena data mengenai jumlah wanita karir sesuai kriteria di bank-bank tersebut sulit didapat karena keterbatasan akses.

Dengan mempertimbangkan waktu dan biaya maka peneliti tidak akan menghitung jumlah populasi dari objek penelitian ini. Menurut Roscoe, dalam penelitian multivariate sample size seharusnya beberapa kali (10 kali atau lebih) dikali jumlah variabel dalam penelitian (Sekaran 2000). Dari 130 kuesioner yang dibagikan hanya 105 yang kembali dan hanya 91 yang lengkap untuk digunakan. Teknik penarikan sampel dilakukan dengan teknik convinience sampling. Hanya calon responden yang dapat ditemui pada saat kunjungan yang dijadikan sampel.

\section{Measurement Instruments \\ Career Management}

Dikembangkan dari Chen et al.,(2010) dan Kong et al., (2011) diukur dengan skala 1 sampai 10 yang menggambarkan seberapa setuju responden terhadap pernyataan itemitem dalam indikator seperti Career management direpresentasikan indikator career appraisal, career development dan career training. Berikut contoh item dalam variabel ini: "Atasan memberikan dukungan dan mendiskusikan pekerjaan dengan saya".

\section{Career Success Subjective}

Dikembangkan dari Gattiker dan Larwood (1988); Greenhaus (1990); Heslin (2005). SCS digambarkan dalam 4 indikator yaitu Career Choice, Achievement, Rewards dan Pride. Berikut adalah salah satu contoh item dalam indikator yang diukur seberapa setuju dalam skala 1 sampai 10 SCS: "Saya bangga berkarir di tempat saya bekerja saat ini”.

\section{Work-Life Balance}

Dikembangkan dari MasMachuca et al., (2016); Hudson (2005); Crooker (2002); digambarkan dalam 4 indikator yaitu work, family time, community, leisuretimes dengan pernyataan seberapa setuju dalam skala 1 sampai 10. Salah satu contoh item dalam indikator family time yaitu: "Hubungan dan peran saya dalam keluarga selalu menyenangkan".

\section{Job satisfaction}

Menggunakan indikator yang dikembangkan Spector (1997) yaitu work it self, reward, relation, job in general, dan growth yang diukur dalam skala 1 sampai 10 untuk menyatakan setuju. Berikut contoh item dalam kuesioner: "Saya puas dengan hubungan 
saya dengan rekan kerja yang selalu baik."

\section{Statistical Analysis}

Uji Validitas, pengujian ini bertujuan untuk mengetahui apakah alat ukur yang digunakan dalam penelitian ini sudah tepat. Tiap item dalam kuesioner dalam 10 skala pengukuran. Oleh karena itu peneliti ingin memastikan apakah item pertanyaan atau instrumen yang digunakan dalam penelitian ini memang mengukur konstruknya. Pengujian validitas dilakukan dengan menggunakan confirmatory analisis faktor (KMO Barllett test).

Pengujian terhadap hipotes is penelitian seperti yang tertuang dalam model penelitian menggunakan SPSS V.22 dan macro dari Hayes V. 2013. Di samping itu, analisis dan kajian juga dilakukan dengan menggunakan mean score dari jawaban yang diberikan responden terhadap tiap item variabel dan dimensinya. Analisis deskriptif diharapkan dapat memberikan gambaran karakteristik jawaban responden.

\section{HASIL DAN PEMBAHASAN Profile Responden}

Responden penelitian ini adalah karyawan wanita yang bekerja di Bank. Semua responden telah menikah dan mempunyai anak, sesuai dengan tujuan untuk menguji efek work-life balance dan kesuksesan karir subjektif pada pengaruh manajemen karir terhadap kepuasan kerja. Seluruh responden telah bekerja lebih dari 3 tahun dengan kisaran usia 25 sampai 50 tahun dan berpendidikan sarjana. Dari 130 kuesioner yang disebar dengan teknik convenience sampling hanya 105 eksemplar yang kembali (80\%). Dari
105 eksemplar yang kembali hanya 91 eksemplar (90\%) yang terisi lengkap dan dapat digunakan dalam penelitian.

\section{Validitas dan Reliabilitas}

Untuk variabel career management uji validitas dilakukan dengan EFA. Dari hasil uji pada factor career management ditemukan hasil yang tidak konsisten dengan hasil uji Kong et al., 2012; Kong et al., 2014) yang mana career management yang diekstrak dalam 3 faktor 12 item memiliki loading yang tinggi pada factor 1 sedangkan 1 item loading di factor 3 yaitu item dual ladeers. Dengan demikian career management tidak dinyatakan dalam 3 faktor. Ketika dimensi career development di uji partial, loading factor untuk item dual ladders juga rendah yaitu 0,214 sehingga item ini akhirnya di drop dari variaabel career management. Hasil analisis faktor dan reliabilitas untuk tiap variabel dapat dilihat berikut ini:

Tabel 1

Hasil Uji Analisis Faktor dan Reliabilitas

Facto

\begin{tabular}{llll} 
Item & $\mathbf{r}$ & $\begin{array}{c}\text { Eigen } \\
\text { Value }\end{array}$ & $\begin{array}{l}\text { Mean } \\
\text { Score }\end{array}$ \\
\hline $\begin{array}{l}\text { Career } \\
\text { Management }\end{array}$ & 7.512 & 7.37 \\
& & &
\end{tabular}

$\begin{array}{lll} & 0.85 & \\ \text { Career advice } & 8 & 7.85 \\ & 0.86 & \\ \text { Appraisal } & 7 & 7.86 \\ \begin{array}{l}\text { Career } \\ \text { discussion }\end{array} & 0.67 & \\ & 4 & 7.23 \\ \text { Clear feedback } & 0.66 & \\ & 1 & 7.53 \\ \begin{array}{l}\text { Organizational } \\ \text { Support }\end{array} & 0.77 & \\ \text { Financial } & 0.80 & 7.38 \\ \end{array}$




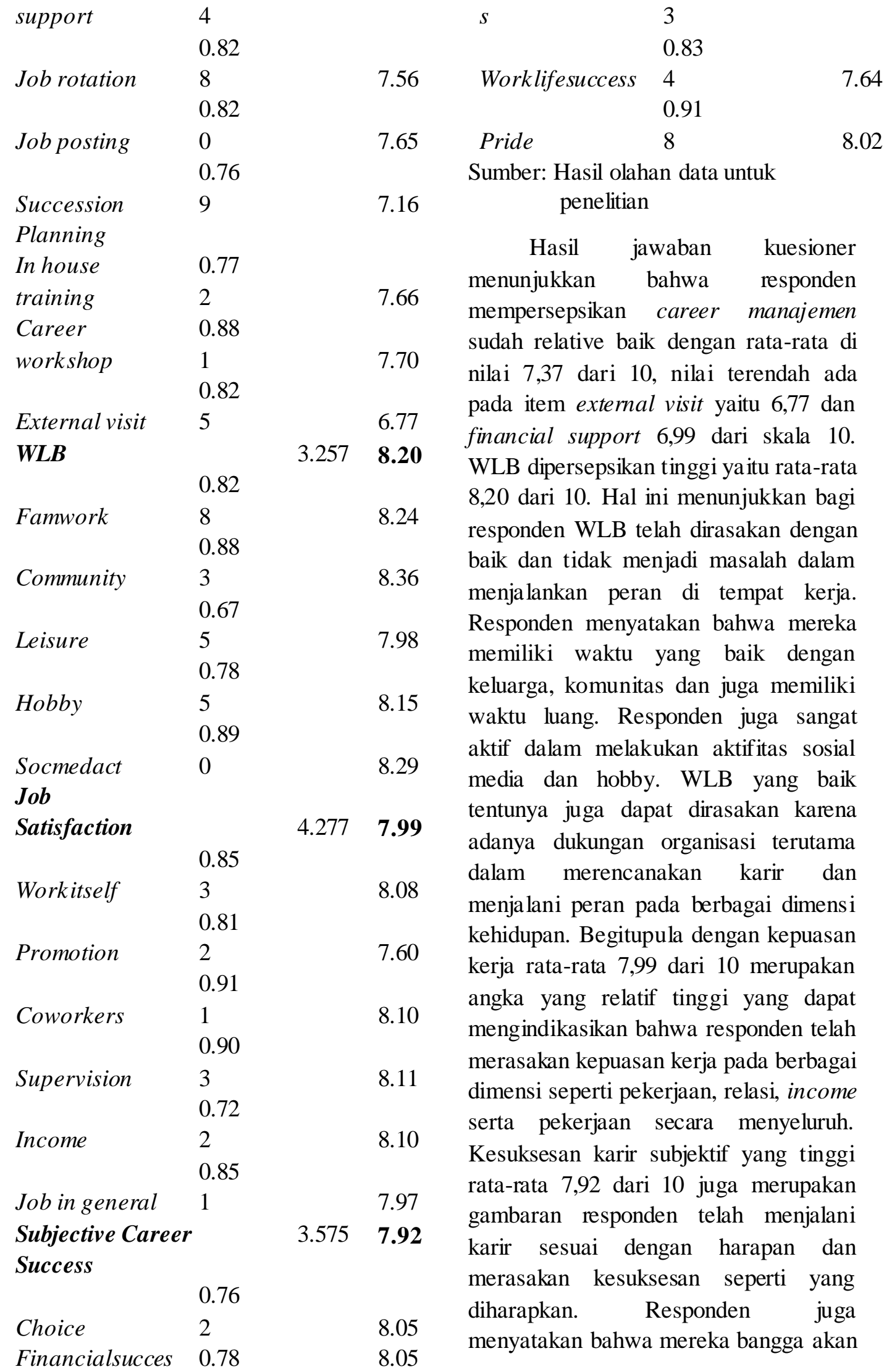


pekerjaannya, merasakan keseimbangna kerja dan hidup serta memiliki penghasilan yang baik. Dari nilai mean score disimpulkan, persepsi responden terhadap career management meski relatif tinggi namun lebih rendah dari outcomenya dibanding work-life balance, subjective career success, dan job satisfaction.

Hasil uji analisis jalur inderect effect dengan olahan SPPS V.22 menggunakan macro Hayes 2013 tersaji pada tabel berikut:

Tabel 3

Hasil Analisis Jalur

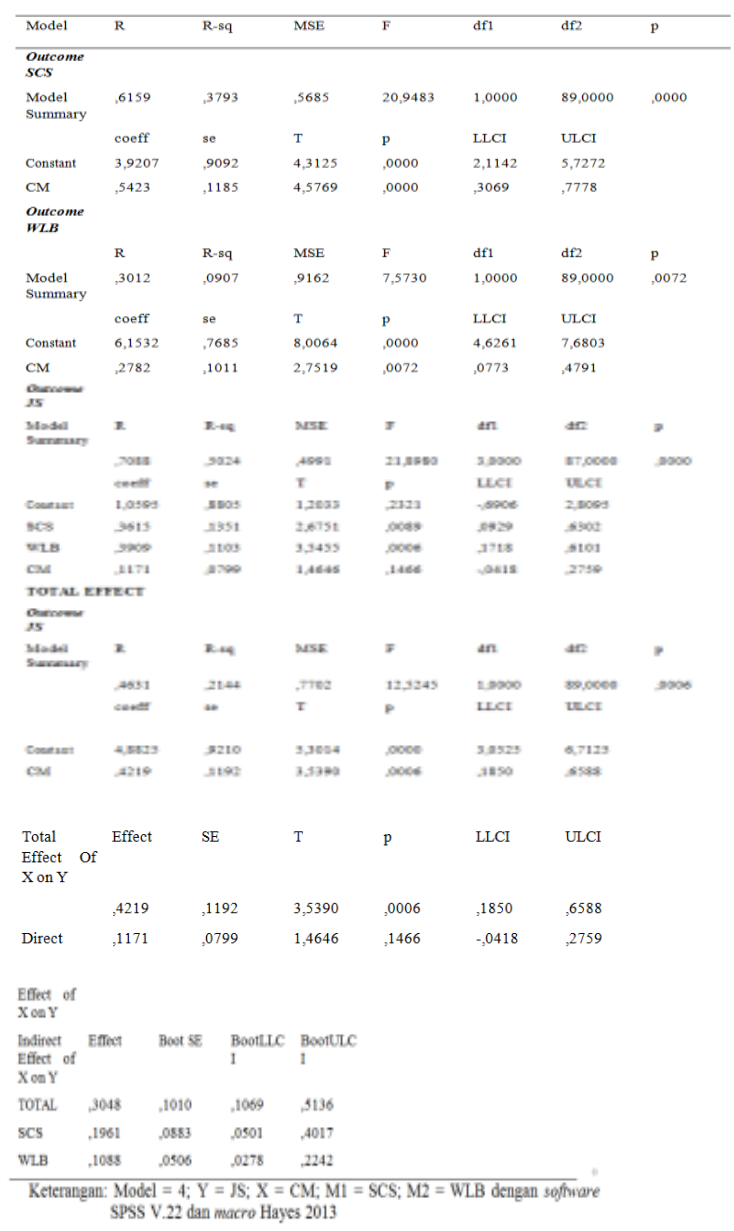

\section{Pembahasan}

Sesuai dengan pengujian hipotesis dengan analisis jalur maka hasil uji menunjukkan model analisis jalur dengan outcome job satisfaction adalah fit dengan $\mathrm{R}$ square yang moderat di angka 50,24 \% dengan p 0.000. Career management berpengaruh signifikan meningkatkan subjective career success terbukti signifikan dengan p 0,000 dengan $\mathrm{R}$ square $37,93 \%$ dan koefisien pengaruh 0.5423. Dari hasil tersebut hipotesis 1 dapat diterima, artinya responden mempersepsikan bila karir mereka dikelola dengan baik maka kesuksesan karir akan diperoleh sesuai dengan tujuan karir sukses yang dipersepsikan secara subjektif. Dari hasil juga diketahui career management yang baik dapat meningkatkan WLB dengan pengaruh yang signifikan pada koefisien 0.2782 dan p 0.0072 namun dengan nilai $\mathrm{R}$ square yg lemah 9,07\%. Dengan demikian hipotesis 2 juga terbukti signifikan.

Sesuai dengan hipotesis $\mathbf{3}$ dan $\mathbf{4}$ maka WLB dan SCS juga terbukti dapat meningkatkan kepuasan kerja dengan $\mathrm{R}$ square 50,24 \% dimana pengaruh WLB signifikan pada p 0,0006 dengan koefisien pengaruh 0,3909 sedangkan SCS signifikan pada p 0,0089 dengan koefisien 0,3615. Namun demikian, hasil tidak dapat membuktikan pengaruh signifikan career management secara langsung terhadap kepuasan kerja dengan p 0,1466 dengan demikian hipotesis 5 tidak terbukti .

Temuan menarik dari hasil penelitian ternyata hipotesis 6 dan 7 yaitu WLB dan SCS terbukti signifikan memediasi pengaruh career management terhadap kepuasan kerja, dengan inderect effect 0,0188 untuk WLB dan 0,1961 untuk SCS. Dengan demikian semua hipotesis kecuali hipotesis 5 terbukti signifikan. Temuan ini menunjukkan bahwa career 
management dapat meningkatkan job satisfaction hanya melalui WLB dan SCS namun tidak dapat berpengaruh langsung.

\section{Theoritical Implications}

Peran ganda wanita sering menjadi dilemma bagi wanita untuk meraih kesuksesan karir dalam bekerja. Kesuksesan karir yang dapat dilihat dalam 2 dimensi yaitu kesuksesan karir objektif dan kesuksesan karir subjektif. Kesuksesan karir subjektif semakin menarik untuk diteliti ketika kesuksesan tidak lagi dipandang sebagai sukses yang hanya diukur dari eksternal outcome semata namun sukses lebih bermakna ketika juga dipandang dari sisi internal individu.

Riset ini membuktikan bahwa bagi wanita dengan peran ganda yang melekat, manajemen karir dapat menjadi faktor yang berkontribusi dalam meningkatkan kesuksesan karir subjektif. Manajemen karir juga dapat meningkatkan work-life balance yang dipersepsikan. Ketika manajemen karir berlangsung dengan baik, maka wanita karir da lam riset ini diketahui merasakan work-life balance yang baik sekaligus kesuksesan karir subjektif yang tinggi.

Penelitian ini juga membuktikan kesuksesan karir subjektif bersama-sama dengan WLB dapat meningkatkan kepuasan kerja yang dirasakan. Hasil riset ini mendukung temuan-temuan dari berbagai riset yang menyatakan bagi wanita karir terutama yang telah menikah dan mempunyai anak, pilihan karir untuk sukses tidak selalu melalui jenjang hirarki namun dapat dilakukan dengan memilih secara tepat waktu berbagi tanggungjawab dalam kehidupan kerja dan keluarga.
Kesuksesan karir subjektif menjadi salah satu variabel pendorong kepuasan kerja bersama-sama dengan WLB.

\section{Practical Implications}

Penelitian ini bertujuan untuk menganalisis bagaimana career management yang diselenggarakan organisasi diyakini dapat meningkatkan kesuksesan karir subjektif, WLB dan kepuasan kerja. Sebagaimana dinyatakan Baruch 2004, bahwa karir pada dasarnya adalah properti individu yang mana tujuan karir dan motivasi karir tidak ditentukan organisasi, namun lebih pada penyesuaian program karir yang dapat diikuti individu secara proakti. Hasil penelitian ini mendukung pernyataan tersebut dimana penanganan manajemen karir terbukti dapat meningkatkan kepuasan kerja melalui WLB maupun subjective career success. Hasil penelitian ini juga relevan mendukung temuan Kong et al., (2014); Ng et al., (2005); Chen et al., (2004); Orpen (1994) yang mana career management signifikan positif bepengaruh terhadap kesuksesan karir. Namun demikian, di sisi lain tidak sesuai dengan temuan Kong et al., (2014) yang membuktikan career management berpengaruh langsung terhadap kepuasan kerja sementara pada penelitian ini manajemen karir tidak signifikan berpengaruh langsung terhadap kepuasan kerja.

Hasil penelitian menunjukkan career management dapat meningkatkan kepuasan kerja dengan mediasi work-life balance (WLB) dan subjective career success (SCS). Dalam manajemen karir, wanita dapat menyesuaikan pemilihan rencana kemajuan karir pada program 
karir yang tersedia dengan mendiskusikannya bersama atasan.

Pemilihan yang tepat akan dapat mendukung WLB. Di sisi lain pilihan rencana karir yang tepat sesuai dengan situasi peran keluarga akan dapat meningkatkan kinerja yang menjadi indikator dari pencapaian (prestasi), sekaligus dapat menjalankan peran ganda yang harmonis. Hal tersebut menjadi gambaran sukses secara subjektif. Hasil ini menggambarkan kehadiran WLB dan persepsi kesuksesan karir subjektif memberi dampak signifikan bagi responden (wanita) untuk mewujudkan kepuasan kerja. Hal ini relevan dengan beberapa temuan seperti Stroh et al., (1996) yaitu workfamily conflict (WFC) dapat menurunkan kepuasan karir; Van Vianen dan Fischer (2002) yaitu WFC berkaitan dengan kendala karir; Finegold dan Mohrman (2001) yaitu WLB faktor kesuksesan karir; Boyar et al.,(2008) yaitu tuntutan keluarga berpengaruh pada karir; Cohen (2007) tentang kesuksesan karir guru wanita.

Hasil penelitian juga sesuai dengan temuan yaitu kesuksesan subjektif diartikan sebagai penilaian individu dalam pencapaian karirnya (Stumpf, 2012; Seibert dan Kraimer, 2001); penilaian terhadap kemampuan diri (Chang et al., 2012) dan kepuasan yang dialami Burke (2001), dan penelitian Santos (2015); Ussher et al., (2015); Afiouni dan Karam, (2014) tentang kesuksesan karir yang selalu dihubungkan dengan situasi keluarga.

\section{BAB V KESIMPULAN DAN KETERBATASAN \\ Kesimpulan}

Sebagaimana telah dijelaskan responden dalam penelitian ini adalah wanita karir yang bekerja di beberapa bank di Jakarta yang telah menikah dan mempunyai anak dan telah bekerja minimal 3 tahun. Dari hasil penelitian para responden terbukti merasakan career management signifikan meningkatkan work-life balance dan kesuksesan karir subjektif. Temuan menarik lainnya, career management tidak berpengaruh langsung terhadap kepuasan kerja, namun dapat berpengaruh melalui WLB dan subjective career success.

Kepuasan kerja yang tinggi tentunya akan berdampak positif bagi kinerja maupun komitmen karyawan. Oleh karena itu perlu diperhatikan manajemen karir yang efektif bagi tiap karyawan wanita agar dapat merasakan kesuksesan karir dan sekaligus terwujudnya WLB. Manajer diharapkan dapat menyelenggarakan manajemen karir yang berkaitan dengan sistem appraisal yang jelas, konseling, development, dan sistem pelatihan yang efektif. Manajemen karir tidak sematamata menyiapkan promosi tetapi lebih mengintegrasikan karir secara komprehensif bagi wanita agar dapat merasakan keseimbangan work-life, karena terbukti WLB penting dalam meningkatkan kepuasan kerja wanita karir.

Hasil penelitian ini juga membuktikan pengelolaan karir (career management) bagi wanita karir terutama yang bekerja di sektor perbankan menjadi variabel penting. Kesempatan dalam mengikuti program pelatihan 
akan dapat meningkatkan skill yang pada akhirnya akan meningkatkan kemampuan berprestasi dalam subjective career success, mendiskusikan karir dengan organisasi yang tentunya dapat diikuti dengan pemberian advice terkait pilihan program yang tersedia. Selanjutnya, career management dapat mendorong wanita karir merasakan kemajuan karir meskipun tidak berada dalam posisi hirarki. Manajemen karir juga memberi kesempatan dalam menunda waktu promosi jabatan apabila situasi keluarga dianggap tidak memungkinkan, namun demikian bukan berarti menghentikan kesempatan bagi orang tersebut. Dengan demikian kesuksesan karir subjektif mampu membuat wanita merasakan kepuasan kerja dari rasa sukses psikologis dan intrinsik.

\section{Keterbatas an}

Hasil penelitian ini tidak dapat di generalized karena teknik sampling yang dilakukan secara convinience, namun penelitian ini dapat menjadi gambaran kasus untuk responden, yaitu wanita karir di beberapa Bank di Jakarta. Selain itu, karena keterbatasan waktu dan dana, penelitian ini juga tidak memiliki jumlah sampel yang cukup untuk diuji dalam SEM untuk menguji model. Penelitian juga dilakukan sangat terbatas pada sejumlah wanita karir di Bank yang dapat diakses saja sehingga data responden tidak bisa dihubungkan dengan karakteristik bank-bank yang terkait. Pengisian jawaban dalam skala untuk tiap item dalam kuesioner tanpa pendampingan karena tidak dimungkinkan, sehingga jawaban yang diberi tidak dapat dikontrol apakah diisi dengan sungguh-sungguh.
Keterbatasan ini juga ikut berkontribusi dalam hasil analisis faktor yang mana variabel career management tidak sesuai dengan hasil konfirmatori pada penelitian sebelumnya yakni memiliki 3 faktorial (Kong et al., 2014), sedangkan dalam penelitian ini terkonfirmasi hanya dalam 1 faktor saja. Oleh karena itu dalam penelitian mendatang sebaiknya sampel diperbesar dan dari berbagai profesi, didampingi dalam pengisian kuesioner. Keterbatasan lain dalam penelitian ini adalah tidak menguji faktor demografis lainnya seperti umur, pendapatan maupun posisi jabatan sebagai kontrol variabel karena beberapa responden tidak mengisi secara jelas terutama posisi jabatan.

\section{DAFTAR PUSTAKA}

Afiouni, Fida. and Charlotte M. Karam. 2014. Structure, agency, and notions of career success. A process-oriented, subjectively malleable and localized approach.Career Development International 19 (5):548-571.

Arthur, M. B., S. N. Khapova, and C. P. M. Wilderom. 2005. Career success in a boundaryless career world. Journal of Organizational Behavior 26:177-202.

Arthur, M. B., and D. M. Rousseau. 1996. The boundaryless career. New York: Oxford University Press.

Aryee, S., H. HoonTan, and E. S. Srinivas. 2005. Rythms of life: Antecedents and outcomes of workfamily balance in employed 
parents. Journal of Applied Psychology 90 (1):132-146.

Anderson, D. M., K. Birkeland, and L. Gidding. 2010. Employee opinion on work family benefits: evidence from the U.S. New Zealand Journal of Employment Relations 34 (3):2642.

Barnett, Belinda, R. and Lisa, Bradley. 2007. The impact of organisational support for career development on career satisfaction. Career Development International 12 (7):617-636

Bartolome, F., and P. Evans. 1981. Must success cost so much? edited by B. Books. New York.

Baruch, Y. 2004. Transforming careers: From linear to multidirectional career paths - organisational and individual perspectives. Career Development International 9 (1):58-73.

Bielby, D. D. 1992. Commitment to Work and Family. Annual Review of Sociology 18:281-302.

Bowen, D., and R. Hisrich. 1986. The female entrepreneur: A Career Development Perspective. The Academy of Management Journal 11 (2):393-406.

Boyar, S. L., J. Maertz, P. Carl, J. Mosley, C. Donald, and J. C. Carr. 2008. The impact of work/family demand on work-family conflict. Journal of Managerial Psychology 23 (3):215-235.
Burke, RJ. 2001. Managerial women"s career experiences, satisfaction and well-being: A five country study. Cross Cultural Management 8: 117-133.

Cappelli, P. 2000. A Market Driven Approach to Retaining Talent: Harvard Business School Publishing Corporation.

Chen, T. Y., P. L. Chang, and C. W. Yeh. 2004. An investigation of career development programs, job satisfaction, professional development and productivity: The case of Taiwan. Human Resource Development International 7 (4):441-463.

Cochran, L. R. 1990. The sense of vocation: A study of career and life development. In $P$. Heslin, Conceptualizing and evaluating career success. Journal of Organizational Behavior, 26.

Cohen, A., L. Granot-Shilovsky, and Y. Yishai. 2007. The relationship between personal, role, and organizational variables and promotion to managerial positions in the Israeli educational system. Personel Review 36 (1).

Cooper, D. R. and P. S. Schindler. 2000. Business research methods. seventh ed. New York Irwin/ McGraw- Hill

Crompton, R., and C. Lyonette. 2006. Work-life „balance in Europe. Acta Sociologica 49:379. 
Crooker, K. J., F. L. Smith, and F. Tabak. 2002. Creating Work-Life Balance: A Model of Pluralism Across Life Domains. Human Resource Development Review 1 (4):387-419.

Dobrow, S. R. 2004. Extreme subjective career success: a new integrated view of having a calling. Paper read at Academy of Management Conference

Farmer, H. S. 1985. Model of career and achievement motivation for women and men.Journal of Counseling Psychology 32:363-390.

Finegold, D., and S. A. Mohrman. 2001. What do employees really want? The perception vs. the reality. In The annual meeting of The World Economic Forum. Davos, Switzerland.

Fonseca, M., and A. Verma. 2001b. Learning and Work-Life Balance in Canada: Evidence from the General Social Survey. In the CIRA XXXVIII Annual Conference Quebec City.

Gattiker, U. E., and L. Larwood. 1988. Predictors for managers' career mobility, success, and satisfaction. Human Relations 41:569-591.

Gattiker, U. E., and L. Larwood. 1990. Predictors for managers' career mobility, success and satisfaction. Human Relations 41 (8):569-591.

Grant, R. M. 1991. The Resource-Based theory of competitive advantage: $\begin{aligned} & \text { Implication for } \\ & \text { formulation. }\end{aligned}$
Management Review, 114-135.
California:

Greenhaus, J. G., G. A. Callanan, and V. M. Godshalk. 2000. Career management 3rd ed. New York: The Dryden Press.

Hadiz, L., and S. W. Eddyono. 2005. Pembakuan peran gender dalam kebijakan-kebijakan di Indonesia. Jakarta: LBH APIK.

Hall, D. T., and Associates. 1996. The career is dead-long live the career: A relational approach to careers. San Francisco: Jossey-Bass.

Hall, D. T., and D. E. Chandler. 2005. Psychological Success: When the Career Is a Calling Journal of Organizational Behavior 26 (2):155-176.

Herman, C. 2006. Achieving a harmonious work life balance: myth or reality? Experiences of women returning to work in science engineering and technology in the UK. In Science Policy Meets Reality Conference Prague.

Heslin, P. 2005. Conceptualizing and evaluating career success. Journal of Organizational Behavior 26.

Hogarth, T., C. Hasluck, G. Pierre, M. Winterbotham, and D. Vivian. 2000. Work-Life Balance 2000:Results from the Baseline Study. In Research Report RR249: Departmen for Education and employment. 
Hudson, A. 2005. The case for work/life balance: Closing the gap between policies and practice.

Hughes, Everett (1937; 1958) dalam Heslin, P. 2005. Conceptualizing and evaluating career success. Journal of Organizational Behavior 26.

Jepsen, D. A., and H. B. Sheu. 2003. General job satisfaction from a developmental perspective: Exploring choice-job matches at two career stages. The Career Development Quarterly 52 (2):162171.

Johnson, C. D., and G. S. Stokes. 2002. The meaning, development, and career outcomes of breadth of vocational interests. Journal of Vocational Behavior 61:327-347.

Judge, T. A., D. M. Cable, J. W. Boudreau, and R. D. J. Bretz. 1995. An empirical investigation of the predictor of executive career success. Personnel Psychology 48.

Kalleberg, A. L. 1977. Work values and job rewards: a theory of job satisfaction.American Sociological Review 42:124-143.

Kong, Haiyan., Catherine, Cheung, and Hanqin, Qiu, Zhang. 2010. Career management systems: what are China ${ }^{e e s}$ state-owened hotels practising. International Journal of Contemporary Hospitality Management. 22 (4):467-482.

Kong, H., Cheung, C. and Song, H. 2012. Determinans and outcome of career competencies: perspectives of hotel managers in China. International Journal Hospitality Management 30(3):712-719.

Kong, Haiyan., Sujuan, Wang, and Xingxing Fu. 2015. Meeting career expectation: can it enhance job satisfaction of generation $\mathrm{Y}$. International Journal of Contemporary Hospitality Management 27 (1): 147-168.

Kossek, E. E., and C. Ozeki. 1998. Work-family conflict, policies, and the job-life satisfaction relationship: A review and directions for organizational behavior-human resources research. Journal of Applied Psychology 83 (2):139-149.

Law, B., F. Meijers, and G. Wijers. 2002. New perspectives on career and identity in the contemporary world. British Journal of Guidance and Counselling 30:431-449.

Lazar, L., C. Osoian, and P. Ratiu. 2010. The role of WLB practices in order to improve organizational performance. European Research Studies 13 (1).

Lewison, J. 2006. The work/life balance sheet so far. Journal of Accountancy 202 (2):45.

Locke, E. A. 1990a. The motivation sequence, the motivation hub, and the motivation core. Organizational Behavior and Human Decision Processes 50:288-299.

Malik, M. I., F. Salem, and M. Ahmad. 2010. Work-life balance and Job Satisfaction among doctor in Pakistan. South Asian Journal of Management 17 (2):112.

Mas-Machuca, Marta., Jasmina, Berbegal-Mirabent, and Ines Alegre. 2016. Work-life balance 
and its relationship with organizational pride and job satisfaction.Journal of Managerial Psychology. 31(2): 586-602.

Michalos, A. C. 1985. Multiple discrepancies theory (MDT). Social Indicators Research 8:385-442.

Ng, Thomas W.H., Lillian T. Eby, Kelly L. Sorensen, and Daniel C. Feldman. 2005. Predictors of objective and subjective career success: a meta -analysis. Personnel Psychology 58: 367-408.

Nikandrou, I., L. Panayotopoulou, and E. Apospori. 2008. The impact of individual and organizational characteristics on work-family conflict and career outcomes. Journal of Managerial Psychology 23 (5):576-598.

Orpen, C. 1998. The effects of performance measurability on the relationship between careerist attitudes and success. Journal of Social Psychology 138 (1):128-130.

Pasewark, W. R., and R. E. Viator. 2006. Sources of Work-Family Conflict in the Accounting Profession. Behavioral Research in Accounting 18:147.

Perrons, D.2003. The new economy and the WLB: Conceptual explorations and a case of new media. Gender Work and Organizations 10 (1).

Quesenberry, J. L., and E. M. Trauth. 2007. The role of ubiquitous computing in maintaining WLB: perspectives from women in the information technology workforce Paper read at Proceeding in School of Information Sciences and Technology at PA U.S.A.

Quick, James, Campbell, and Debra L. Nelson., 2011. Principles of
Organizational Behavior. Seventh edition. South-Western: Cengage Learning

Rasdi, Roziah.M., Maimunah, Ismail, Jegak, Uli, and Sidek, Mohd, Noah. 2009. Towards developing a theoritical framework for measuring public sector managerse career success. Journal of Europian Industrial. 33 (3):232-254.

Said, Al-Mansor, Abu., Roziah, Mohd, Rasdi., Bahaman, Abu, Samah., Abu, Daud, Silong., Suzaimah, Sulaiman. 2015. A career success model for academics at Malaysian research universities. Europian Journal of Training and Development. 39(9): 815-835.

Santos, G.G. (2015) Narratives about work and family life among Portuguese academics. Gender, Work \& Organization, 22,1, 1-15.

Saltzstein, A. L., YuanTing, and G. H. Saltzstein. 2001. Work-Family Balance and Job Satisfaction: The Impact of Family-Friendly Policies on Attitudes of Federal Government Employees. Public Administration Review 61 (4):452467.

Scandura, T. A., and M. J. Lankau. 1997. Relationships of gender, family responsibility and flexible work hours to organizational commitment and job satisfaction. Journal of Organizational Behavior 18 (4):377-391.

Schein, E. H. 1978. Career dynamics: Matching individual and organizational needs In Heslin, P. (2005). Conceptualizing and evaluating career success. Journal of Organizational Behavior, 26. 
Schilling, E. 2012. Between security and professional exclusion: Career linearity and work-life-balance in German and Russian public administration. Cologne, Germany: University of Applied Administrative Sciences NRW.

Schneer, J. A., and F. Reitman. 1993. Effects of alternate family structure on Managerial Career Paths. The Academy of Management Journal 36 (4):880-843.

Seibert, S. E., and M. L. Kraimer. 2001. The five-factor model of personality and career success. Journal of Vocational Behavior 58:1-21.

Sekaran, U. 2000. Research Methods for business: A skill-building approach. 3rd ed: John Wiley \& Son, Inc.

Shujaat, S., Sana, S., Aftab, F. \& Ahmed, I. 2013. Impact of career development on employee satisfaction in private banking sector Karachi. Journal of Management and Social Sciences. 9(2) 1-8.

Sonnenfeld, J., and J. P. Kotter. 1982. The maturation of career theory. Human Relations 35:19-46.

Spector, P.E. (1997). Job Satisfaction: Application, Assessment, Causes, and Consequences. London: Sage Publications.

Straub, C. 2007. A comparative analysis of the use of work- life balance practices in Europe.Do practices enhance females ${ }^{\text {ee }}$ career advancement? Women in Management Review 22 (4):289304.

Stroh, L. K., J. M.Brett, and A. H. Reilly. 1996. Family, structure, glass ceiling, and traditional explanations for the different rate of turnover of female and male managers. Journal of Vocational Behavior 49:99-118.

Stumpf, S. A., \& Tymon, W.G. 2012. The effects of objective career success on subsequent subjective career success. Journal of Vocational Behavior. 81(3):345353

Sullivan, S. E. 1999. The changing nature of careers: a review and research agenda. Journal of Management \& Organization 25:457-484.

Thompson, C. A., and D. Prottas. 2005. Relationships among organizational family support, job autonomy, perceived control, and employee well-being. Journal of Occupational Health Psychology 11 (1):100-118

Tremblay, Michel., Jacqueline, Dahan, and Martina, Gianecchini. 2014. The mediating influence of career success in relationship between career mobility criteria, career anchors and satisfaction with organization. Personnel Review 43(6): 818-844.

Trenbunsel, A. E., J. M. Brett, E. Maoz, L. K. Stroh, and A. H. Reilly. 1995. Dynamic and static work-family relationships. Organizational Behavior and Human Decision Processes 63 (3):233-246.

Ussher, Sarah., Maree, Roche, and Donald, Cable. 2015. Women and Careers: New Zealand women"s engagement in career and family planning. New Zealand Journal of Employee Relations 40 (3): 24-43. 
Vianen, V., E. M. Annelies, and A. H. Fischer. 2002. Illuminating the glass ceiling: The role of organizational culture preferences. Journal of Occupational and Organizational Psychology 75 (3):315-337.

Warren, T., E. Fox, and G. Pascall. 2009. Innovative social policies: Implications for work-life balance among low waged women in England. Gender, Work and Organization 16 (1).

Wrzesniewski, A. 2002. It's not just a job': shifting meanings of work in the wake of 9/11. Journal of Management Inquiry 11:230-235.

Zeytinoglu, I. U., M. Denton, S. Davies, A. Baumann, J. Blythe, and L. Boos. 2007. Associations between work intensification, stress, and job satisfaction, the case of nurses in Ontario. Relations Industrielles 62 (2):201. 